\title{
Considerações sobre a questão da política no pensamento de Antônio Gramsci
}

\section{Considerations on the question of politics in the thought of Antônio Gramsci}

\begin{abstract}
Resumo: $O$ presente artigo trata de tematizar alguns dos fundamentos teórico-analíticos do tratamento da questão da política no pensamento de Gramsci contidos nos Cadernos do Cárcere, em particular Estado integral, hegemonia, catarse, partido e revolução e suas orgânicas relações com as determinações do "mundo da produção" e com a práxis política. Nosso objetivo é apresentar a ideia da política, no sardo comunista, como uma mediação insuprimível para a construção de processos que nos levam à superação da ordem do capital e à construção da "sociedade regulada", nome que Gramsci usava para se referir ao comunismo.
\end{abstract}

Palavras-chave: Infraestrutura-superestrutura. Política. Sociedade regulada

\author{
Maria Lúcia Duriguetto* \\ Rodrigo de Souza Filho**
}

\begin{abstract}
The aim of this article is to discuss the Gramsci's theorical grounds about your conception of politic that is found on the Prison Notebooks. We present Gramsci's subjects as Total State, Hegemony, Catharsys, Political Party, Revolution and their organic links with the determinations of the "forces/relations of production" and with the political praxis. Our goal on this article is to demonstrate that the idea of politic is a necessary mediation to set up processes that lead us to overcome the capital order. Furthermore it's a important way to build a regulated society, the name used by Gramsci as reference to communism.
\end{abstract}

Keywords: Infrastructure-superstructure. Politic. Regulated society

Recebido em: 19/04/2021

Aprovado em: 10/05/2021

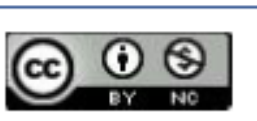

(C) $\mathrm{O}$ (s) Autor(es). 2018 Acesso Aberto Esta obra está licenciada sob os termos da Licença Cccegtive

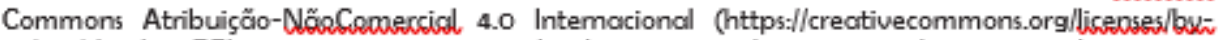
$\mathrm{as} / 4.0 /$ deednt. $\mathrm{BD}$ ), que permite copiar, distribuir e reproduzir em qualquer meio, bem como adaptar, transformar e criar a partir deste material, desde que para fins não comerciais e que você forneça o devido crédito aos autores e a fonte, insira um link para a Licença Scceqtive. Commons e indique se mudanças foram feitos.
}

\footnotetext{
* Graduação em Serviço Social pela Universidade Federal de Juiz de Fora, Mestrado e Doutorado em Serviço Social pela Universidade Federal do Rio de Janeiro e Pós-Doutorado pela Universidade da Calábria - Itália. Professora Titular da Faculdade de Serviço Social da Universidade Federal de Juiz de Fora. Temáticas: Serviço Social; Movimentos sociais; Democracia. Membro do Grupo de Pesquisa "Serviço Social, Movimentos Sociais e Políticas Públicas". Bolsista PQ2 CNPq.

** Graduação em Serviço Social pela Universidade Federal do Rio de Janeiro, Mestrado e Doutorado em Serviço Social pela Universidade Federal do Rio de Janeiro. Professor Associado da Universidade Federal de Juiz de Fora. Desenvolve estudos e pesquisas na área de Serviço Social e Gestão, com ênfase nos seguintes temas: administração pública, gestão social e política social. Membro do Grupo de Pesquisa "Serviço Social, Movimentos Sociais e Políticas Públicas".
} 


\section{Introdução}

A questão da política é apreendida, por Gramsci, como modalidade de práxis que se desenvolve de forma mais imediata na esfera da superestrutura, nela expressando tanto formas de consciência que tendem a atuar nos conflitos cotidianos - derivando práticas políticas restritas ou o que denominou "pequena política" quanto e, principalmente, como modalidade de práxis que contém o elemento catártico, que pressupõe um processo de elevação da consciência formada nas determinações imediatas da vida cotidiana à consciência da universalidade do gênero humano - que ele denominou de "momento ético-político". O sardo comunista se dedicou a refletir acerca da fundamentação da política, em sentido amplo, e dos processos que podem fomentar e induzir ao desenvolvimento dessa segunda acepção de política como forma de elaborar uma crítica radical ao economicismo que imperou na Segunda e Terceira Internacionais. Nosso foco, neste artigo, é apresentar alguns apontamentos sobre essa reflexão ${ }^{1}$.

De acordo com Coutinho (2011: 21), as principais contribuições de Gramsci ao desenvolvimento do pensamento marxista não se situam no estrito terreno da crítica da economia política ${ }^{2}$. Embora o marxista italiano jamais tivesse negado a centralidade das relações sociais de produção na explicação da vida social, concentrou sua atenção nas esferas da política e da ideologia, elaborando uma articulação na qual as superestruturas ideológicas, longe de aparecerem como simples reflexos passivos da base econômica, têm sua autonomia relativa grandemente ampliada. Sua atenção voltou-se para a questão da política ${ }^{3}$ enquanto esfera com estatuto, legalidade e relevância específicos. A apreensão da política como sinônimo de catarse possibilitou a Gramsci, segundo Coutinho, a elaboração de "uma autêntica ontologia materialista e dialética da práxis política", que nos permite encontrar na sua obra "uma crítica

\footnotetext{
${ }^{1}$ Este artigo apresenta uma versão revista e ampliada do artigo A importância da "política" no pensamento de Gramsci, publicado pela Revista Educação e Fronteiras On-Line, Dourados/MS, v.4, n.11, p.5-20, mai./ago. 2014. Possui um caráter introdutório e didático ao tema da questão da política em Gramsci visando, principalmente, contribuir para a introdução dos/as discentes de graduação e pós-graduação em Serviço Social ao tema.

${ }^{2}$ Segundo Coutinho (1994: 102), Gramsci partiu do pressuposto de que a "crítica da economia política já havia sido feita": ele aceita integralmente os resultados dessa crítica, tanto os produzidos pelo próprio Marx quanto, e talvez, sobretudo, os contidos nos desenvolvimentos que ela encontrou na obra de Lênin, particularmente em " $\mathrm{O}$ imperialismo, fase superior do capitalismo". Para o gramsciano brasileiro, o foco da atenção do marxista sardo "está concentrado, sobretudo, na política (nas novas formas de hegemonia burguesa) e não nas determinações econômicas stricto sensu" (COUTINHO, 1994: 103).

${ }^{3}$ Gramsci, nos Cadernos do Cárcere, desenvolve uma definição da política como práxis possibilitadora da emersão e do desenvolvimento de ações conscientes de pertencimento de classe e de luta pela emancipação humana. Trava um importante combate ao estruturalismo de Bukharin, por este focar a determinação estrutural na condução dos processos sociais, que se desenvolveriam independentemente da vontade e da consciência dos homens. Como elucida Coutinho (1994: 104-5), como fiel herdeiro da "dialética histórica de Marx", para Gramsci "[...] a vida social é produto da ação de sujeitos e, nessa medida, tanto a consciência quanto a vontade dos homens são fatores decisivos (ainda que não absolutos) na construção da objetividade social”.
} 
ontológica da política que, em seus resultados teóricos, cumpre as indicações metodológicas da 'crítica da economia política' marxiana [...]”' (COUTINHO, 1994: 159).

Assim, tal como em Marx, também em Gramsci, o conjunto das relações sociais de produção constituem determinações que limitam e condicionam historicamente o campo de alternativas que se colocam à ação humana. Gramsci se importará com os elementos de preparação das condições e processos político-ideológicos da práxis revolucionária, uma vez que, de acordo com o método dialético, a vida social, síntese da estrutura e superestrutura, é um terreno dinâmico de alternativas, não havendo situação histórica que não possa ser transformada pela livre, consciente e organizada ação humana, a qual se desenvolve nos contextos dos condicionamentos sociais que a determina ${ }^{4}$.

É importante enfatizar que, em Marx, o primado das categorias econômicas decorre do significado central que tem o trabalho como estrutura fundante da objetivação social e das relações humanas. Não obstante, as relações econômicas e o complexo categorial que Marx desenvolveu para elucidá-las na sua crítica da economia política não podem ser, simplesmente, transferidos mecanicamente para todo o conjunto das inter-relações sociais, notadamente nos complexos categoriais presentes na esfera da superestrutura. O específico destas necessita ser desvelado em suas particulares mediações internas e em suas interligações estruturais com o "mundo da produção". É este o caminho reflexivo que Gramsci desenvolve em relação à questão da política, o que em definitivo retira qualquer suposto (e falso) politicismo na sua acepção desta categoria. A seguir, apresentaremos, de forma sumária e esquemática, eixos de análise que o comunista italiano desenvolveu a partir de sua arguta observação dos processos sócio-históricos desenvolvidos em algumas formações econômico-sociais, notadamente a italiana.

\section{A questão da política nos processos de ruptura com a ordem do capital: estrutura, superestrutura, Estado integral e hegemonia}

Nosso objetivo, neste item, é expor elementos do caminho reflexivo que Gramsci trilhou para tematizar, problematizar e prospectivar os processos econômico-políticos que perfazem a dinâmica das lutas de classes, caminho que posiciona seu pensamento de forma diametralmente oposta a qualquer derivação reformista e/ou politicista. Portanto, a finalidade última aqui é contribuir no refutamento às interpretações reformistas e/ou politicistas das formulações gramscianas no campo da tradição marxista ${ }^{4}$.

\footnotetext{
${ }^{4}$ Por não ser nosso foco aqui, não trataremos, também de refutar, interpretações liberais e "culturalistas" do pensamento de Gramsci, tão em voga no debate acadêmico.
} 
Em nosso entendimento, algumas das questões centrais que fazem com que certos intérpretes tratem Gramsci como reformista e/ou politicista referem-se à forma não dialética de compreensão do seu pensamento acerca da relação existente entre estrutura e superestrutura; dos momentos processuais revolucionários, que nominou de "guerra de movimento" e "guerra de posição"; e à forma (equivocada) que se interpreta a questão da sua tematização sobre a questão da reforma. Vejamos primeiro este último aspecto.

A reforma, na interpretação de determinados autores críticos a Gramsci, vem sempre subordinada à ordem. Ou seja, a reforma é algo que possui como horizonte a sociabilidade burguesa, sendo esta a perspectiva do "novo reformismo burguês" Netto (1992). Não temos dúvida que existe uma acepção de reforma que a subsume aos limites do projeto societário burguês em seus diferentes matizes. Portanto, que não implica em perspectivas e processos que coloquem a ordem do capital em questão ${ }^{5}$.

Gramsci rechaça radicalmente essa orientação. Ao tratar da questão da reforma ou mais exatamente da "reforma intelectual e moral" além de indicar, claramente, que se trata de um processo de construção de condições para o "desenvolvimento da vontade coletiva nacionalpopular no sentido de uma forma superior e total de civilização moderna", explicita que essa construção deva estar vinculada a um programa de reforma econômica. Em outras palavras, ressalta que o "programa de reforma econômica é exatamente o modo concreto através do qual se apresenta toda a reforma intelectual e moral" (GRAMSCI, 2000b, p.18-9). Assim, a perspectiva de reforma adotada pelo sardo comunista implica o horizonte de uma sociabilidade superior cuja materialização encontra-se fundada nas condições econômicas da vida social. Ou seja, a reforma indicada não está parametrizada pela ordem do capital e nem se viabiliza desconsiderando os elementos econômicos (objetivos) da realidade. Portanto, longe de uma concepção reformista e/ou politicista. No entanto, para uma maior apreensão desta concepção, em Gramsci, é necessário evidenciar a questão do par dialético estrutura-superestrutura.

É na crítica à construção especulativa do domínio do universal sobre o particular que Marx desenvolve, em meados de 1843, a sua crítica sobre a natureza do Estado moderno e de sua relação com a sociedade civil, como foi definida na filosofia jurídico-política de Hegel. Nesta, o Estado é miticamente transformado no sujeito real que ordena, funda e materializa a

\footnotetext{
${ }^{5}$ As mutações da social democracia europeia na virada do século XIX para o século XX - no que ficou conhecido como "revisionismo" - em particular nos anos de 1930, com a Teoria Geral de Keynes bem como as elaborações teórico-políticas dos chamados liberais democráticos (além de Keynes, as de Beveridge e Marshall) expressam, historicamente, esse movimento revisionista. Cf. Przeworski (1989); Netto (1992).
} 
universalização dos interesses privatistas e particularistas da sociedade civil. É na crítica a essa inversão do universal pelo particular que Marx desenvolve a sua visão do Estado.

Marx, de forma precisa, escreve no "Prefácio" da obra "Para a Crítica da Economia Política" (1859), a real relação que se estabelece entre o Estado e a sociedade civil:

relações jurídicas, tais como formas de Estado, não podem ser compreendidas nem a partir de si mesmas, nem a partir do assim chamado desenvolvimento geral do espírito humano, mas pelo contrário, elas se enraízam nas relações materiais de vida, cuja totalidade foi resumida por Hegel sob o nome de 'sociedade civil', seguindo os ingleses e franceses do século XVIII; mas que a anatomia da sociedade burguesa, deve ser procurada na Economia Política (MARX, 1996: 51).

Para Marx, é na esfera da sociedade civil - que define como a esfera da produção e da reprodução da vida material - que se fundamenta a natureza estatal, e não o contrário, como supunha Hegel. Ou seja, o Estado não funda a dinâmica da sociedade civil, mas a expressa.

na produção social da própria vida, os homens contraem relações determinadas, necessárias e independentes de sua vontade, relações de produção estas que correspondem a uma etapa determinada de desenvolvimento de suas forças produtivas materiais. A totalidade dessas relações de produção forma a estrutura econômica da sociedade, a base real sobre a qual se levanta uma superestrutura jurídica e política, e à qual correspondem formas sociais determinadas de consciência. Em uma certa etapa de seu desenvolvimento, as forças produtivas materiais da sociedade entram em contradição com as relações de produção existentes ou, o que nada mais é que sua expressão jurídica, com as relações de propriedade dentro das quais aquelas até então tinham movido. De formas de desenvolvimento das forças produtivas essas relações se transformam em seus grilhões. Sobrevém então uma época de revolução social. Com a transformação da base econômica, toda a enorme superestrutura se transforma com maior ou menor rapidez (MARX, 1996: 52).

Nos Cadernos, Gramsci trabalhará de forma exaustiva esta indicação marxiana posta no Prefácio, e não abandonará essa orientação. Assim, em nosso entendimento, três aspectos explicitam a concepção gramsciana em relação às esferas da estrutura e da superestrutura: a relação dialética entre ambas; a determinação central da estrutura; e o significado da superestrutura para a compreensão da dinâmica da vida social.

A relação dialética entre estrutura e superestrutura é evidenciada, principalmente, a partir da concepção de Gramsci de bloco histórico. GRAMSCI (2001: 238), destaca que, na totalidade do bloco histórico, as "forças materiais são o conteúdo e as ideologias são a forma, distinção entre forma e conteúdo puramente didática, já que as forças materiais não seriam historicamente concebíveis sem forma e as ideologias seriam fantasias individuais sem as forças materiais". Para Gramsci, "a estrutura e as superestruturas formam um bloco histórico" (GRAMSCI, 2001: 250); o bloco histórico é a "unidade entre natureza e espírito (estrutura e 
superestrutura), unidade dos contrários e dos distintos" (GRAMSCI, 2000b: 26). Assim sendo, a realidade social é constituída por essas duas dimensões, não podendo ser pensada ou reduzida uma ou a outra.

Reforçando esta nossa interpretação, Gramsci, a título de análise crítica à formulação de Nikolai Bukharin contida em sua obra A teoria do materialismo histórico. Manual popular de sociologia marxista (referida nos escritos do cárcere como Ensaio Popular), demonstra que Bukharin reduz a filosofia da práxis (como Gramsci nominava a teoria social de Marx) a uma mera sociologia (GRAMSCI, 2001, p.146). Recorre à elaboração marxiana, acima apresentada, para evidenciar a relação dialética existente entre a estrutura e superestrutura, rechaçando qualquer impostação à esfera econômica como causa última.

O trecho do [prefácio ao] Zur Kritik contém as expressões "grau de desenvolvimento das forças materiais de produção", "modo de produção da vida material", "condições econômicas da produção" e similares, expressões que afirmam certamente ser o desenvolvimento econômico determinado por condições materiais, mas que jamais reduzem essas condições à mera "metamorfose do instrumento técnico". Croce acrescenta, de resto, que o fundador da filosofia da práxis jamais se propôs uma indagação a respeito da causa última da vida econômica. "Sua filosofia não era assim tão barata. Ele não teria 'flertado' em vão com a dialética de Hegel, para logo depois sair buscando causas últimas" (GRAMSCI, 2001: 158).

Portelli (1977: 52-7) apresenta uma análise precisa desta relação ao mostrar que os textos dos Cadernos indicam que tanto a estrutura como a superestrutura são momentos determinantes do bloco histórico, não obstante a constatação do elemento da estrutura econômica como decisivo:

Essa é a razão por que colocar a questão da primazia de um ou outro elemento do bloco histórico é um falso problema. Se considerarmos a articulação desse bloco, fica evidente que sua estrutura sócio-econômica é o seu elemento decisivo. Mas é não menos evidente que, em qualquer movimento histórico, é a nível das atividades superestruturais que se traduzem e resolvem as contradições surgidas na base. A relação entre esses dois elementos é ao mesmo tempo dialética e orgânica (PORTELLI, 1977: 56).

Nesta direção, Gramsci afirma, em diferentes passagens dos Cadernos, que o elemento decisivo do complexo do bloco histórico cabe à dimensão estrutural: o "conjunto complexo e contraditório das superestruturas é o reflexo do conjunto das relações sociais de produção" (GRAMSCI, 2001: 250). Em outras passagens, como na polêmica com as formulações de Croce sobre a dialética, Gramsci sublinha "a prioridade do fato econômico, isto é, da estrutura como ponto de referência e de impulso dialético para as superestruturas, ou seja, os 'momentos distintos do espírito"” (GRAMSCI, 2001: 385).

Em outro momento de seus escritos, quando trata da “Análise das situações. Correlação 
de forças", essa determinação surge de forma explícita. Para Gramsci, o primeiroelemento a ser considerado nesse processo de análise é a dimensão ligada à "estrutura objetiva", para que seja possível "estudar se existem na sociedade as condições necessárias e suficientes para sua transformação", só depois desse nível de análise se deve avaliar a relação das forças políticas Gramsci (2000b: 40) ${ }^{6}$. Não cabe, nesse sentido, qualquer possibilidade de interpretação mecanicista sobre a relação que se estabelece entre o momento determinante central, a estrutura, e seu reflexo, a superestrutura. "A pretensão [...] de apresentar e expor qualquer flutuação da política e da ideologia como uma expressão imediata da infra-estrutura deve ser combatida, teoricamente, como um infantilismo primitivo [...]" (GRAMSCI, 2001: 238). Abrimos, assim, o caminho para o terceiro aspecto que gostaríamos de destacar, o significado da superestrutura na formulação gramsciana.

A superestrutura, na totalidade do bloco histórico, apesar de não ser o elemento determinante central, não se configura como simples aparência ou epifenômeno da estrutura. Possui estatuto e legalidade próprios, a partir de seus nexos com a dimensão objetiva da vida social. Dessa forma, a superestrutura é a dimensão em que as contradições da estrutura se manifestam e torna possível sua resolução a partir da práxis (GRAMSCI, 2001: 250-1). É nessa dimensão que os homens tomam consciência de sua posição social e de seus objetivos (GRAMSCI, 2001: 389). Portanto, o significado da superestrutura no pensamento do marxista italiano refere-se, em termos gerais, à centralidade que esta categoria adquire para a ampliação das reflexões sobre a política no seio da tradição marxista.

Não podemos transformar o esforço crítico-analítico de Gramsci para "combater a abstração mecanicista e o fatalismo determinista" (GRAMSCI, 2000b: 300) da vulgata economicista (bem como o ideologismo voluntarista) num pensamento politicista. Os elementos elencados anteriormente, mesmo que apenas pontuados, nos oferecem indicações precisas sobre o significado da estrutura econômica no desenvolvimento do pensamento gramsciano. Nele, a acentuação dada ao significado e importância da esfera da superestrutura só se tornam honestamente inteligíveis pelos seus intérpretes a partir desta perspectiva e, neste sentido, essa esfera se configura como uma dimensão essencial para a compreensão da questão da política na obra gramsciana.

A partir desta perspectiva, o marxista italiano empreendeu uma formulação original da concepção de Estado, conservando e superando, por meio de novas determinações, a apreensão

${ }^{6}$ É importante destacar, conforme sinaliza Voza (2014: 537), que Gramsci, de forma progressiva, vai abandonando a metáfora estrutura-superestrutura, "mesmo que por um certo período Gramsci continue a utilizá-la, em sentido fraco e/ou polêmico, contra seus interlocutores ideais". 
sobre o fenômeno estatal desenvolvida no âmbito do pensamento marxiano e da tradição marxista do seu tempo histórico.

\section{Estado Integral}

A partir dos conceitos fundantes desenvolvidos por Marx, Engels e Lênin para pensar a sociedade civil e sua relação com o Estado, Gramsci pensa estas categorias a partir de um conjunto de transformações em curso em sua época histórica como a presença de organizações tanto dos trabalhadores quanto do capital no cenário do capitalismo monopolista (partidos políticos, sindicatos); da conquista do sufrágio universal, do fascismo e do nazismo como movimentos de expressão da hegemonia política da burguesia, da complexificação da esfera da cultura, do direito, da ideologia, entre outros.

É com esta configuração da vida social que visualiza uma nova construçãodas relações de poder e de organização de interesses que fazem emergir uma nova dimensão da vida social, a qual denomina de sociedade civil. Essa esfera designaria o espaço em que se manifesta a organização e a representação dos interesses dos diferentes grupos sociais, da elaboração e/ou difusão dos valores, cultura e ideologias ${ }^{7}$. A sociedade civil é parte do Estado, e constitui uma esfera decisiva da luta de classes, na qual os diferentes grupos sociais que se formam a partir de suas inserções no mundo econômico lutam para conservar ou conquistar a hegemonia. Nas palavras de Fontes (2007: 211-2), “o conceito de sociedade civil liga-se ao terreno das relações sociais de produção, às formas sociais de produção da vontade e da consciência e ao papel que, em ambas, exerce o Estado". Ou seja, "a sociedade civil é o momento organizativo a mediar as relações de produção e a organização do Estado, produzindo organização e convencimento".

Essa configuração da sociedade civil é incorporada ao seu entendimento do fenômeno estatal. O Estado integral de seu tempo e contexto, preservando a função de coerção (sociedade política) tal como enfatizada por Marx e Engels (1848), também incorpora a esfera da sociedade civil (cuja função é o consenso): "Estado é todo o complexo de atividades práticas e teóricas com as quais a classe dirigente não só justifica e mantém seu domínio, mas consegue obter o consenso ativo dos governados" (GRAMSCI, 2000b: 331). Portanto, sociedade civil e

\footnotetext{
7 O conceito de sociedade civil em Gramsci pertence, assim, ao momento da superestrutura, diferente da formulação marxiana, que identifica sociedade civil com infraestrutura econômica. Entretanto, esse novo conteúdo da esfera da sociedade civil não significa seu isolamento com relação à estrutura econômica e nem se transforma no momento predominante da dialética estrutura-superestrutrura, como conclui equivocadamente Bobbio (1982: 32). Este, ao fazer uma leitura liberal do conceito de sociedade civil em Gramsci, toma-o exclusivamente como esfera da superestrutura, como se Gramsci conferisse à esfera econômica um papel secundário. Fiel à dialética materialista e historicista marxiana, o pensamento de Gramsci tem na produção e na reprodução da vida material o fator ontologicamente primário para a inteligibilidade da vida social.
} 
sociedade política dão forma e concretude ao que Gramsci nomina de Estado integral.

[...] na noção geral de Estado, entram elementos que devem ser remetidos à noção de sociedade civil (no sentido, seria possível dizer, de que Estado = sociedade política + sociedade civil, isto é, hegemonia couraçada de coerção) Gramsci (2000b: 244).

Ou seja, a sociedade civil gramsciana faz parte do Estado (lato sensu) que, por sua vez, é permeado pelos interesses e conflitos das classes sociais conformadas na estrutura econômica.

A dinâmica que se processa no interior da sociedade política e da sociedade civil revela uma distinção em relação à "função" que exercem na conservação ou transformação das relações de poder entre as classes sociais. Enquanto na sociedade política o conjunto das frações das classes dominantes exercem seu poder e sua dominação por meio dos "aparelhos coercitivos de Estado" (aparato estatal administrativo-burocrático, civil e militar), na sociedade civil esse exercício do poder ocorre por intermédio de uma relação de hegemonia que é construída pela direção política e pelo consenso. Ou seja, a formação e difusão de um consenso - que incorpora e reflete interesses de classes - necessita de uma base socioinstitucional que possua estrutura e legalidade própria. É essa certa autonomia e independência material e funcional dos organismos sociais "privados" em relação aos do "Estado-coerção" (ou sociedade política) que marca o fundamento da sociedade civil e sua função mediadora entre a estrutura econômica e o Estado em sentido estrito ${ }^{8}$.

Fundamental para o sardo comunista é o entendimento do conjunto de mediações que conformam esse domínio e organizam a manutenção do consentimento, pois a capacidade de direção (que envolve o componente ineliminável da coerção) e de garantia consensuada dos subalternos são elementos fundamentais para a manutenção da dominação política da classe que tem a hegemonia na estrutura econômica.

\section{Hegemonia}

É na apreensão das relações de poder materializadas nos campos do bloco histórico em geral e, particularmente, no Estado integral, que Gramsci apreende os conteúdos que materializam as relações de hegemonia ${ }^{9}$, as quais envolvem, dialeticamente, elementos da

\footnotetext{
${ }^{8}$ Assim, para Gramsci (2000b: 254-5), "por Estado deve-se entender, além do aparelho de governo, também o aparelho "privado" de hegemonia ou sociedade civil". Dessa forma, a caracterização da materialidade socioinstitucional da sociedade civil pode ser denominada de "aparelho privado de hegemonia".

${ }^{9}$ Como esclarece Gruppi (2000: 1), "o termo hegemonia deriva do grego eghestai, que significa 'conduzir', 'ser guia', 'ser líder', ou também do verbo eghemoneuo, que significa 'ser guia', 'preceder', 'conduzir', e do qual deriva 'estar à frente', 'comandar', 'ser o senhor'. Por eghemonia, o antigo grego entendia a direção suprema do exército. Trata-se, portanto, de um termo militar. Hegemônico era o chefe militar, o guia e também o comandante do exército".
} 
superestrutura e da estrutura. Nas palavras de Gramsci:

O fato da hegemonia pressupõe indubitavelmente que sejam levados em conta os interesses e as tendências dos grupos sobre os quais a hegemonia será exercida, que se forme um certo equilíbrio de compromisso, isto é, que o grupo dirigente faça sacrifícios de ordem econômico-corporativa; mas também é indubitável que tais sacrifícios e tal compromisso não podem envolver o essencial, dado que se a hegemonia é ético-política, não pode deixar de ser também econômica, não pode deixar de ter seu fundamento na função decisiva que o grupo dirigente exerce no núcleo decisivo da atividade econômica (GRAMSCI, 2000b: 48).

O conceito se refere tantoao processo em que uma classe torna-se dirigente, quanto à direção que uma classe no poder exerce sobre o conjunto da sociedade. Em outras palavras, a hegemonia expressa a direção e o consenso ideológico (de concepção de mundo) que uma classe consegue obter dos grupos próximos e aliados. A construção de uma nova hegemonia também implica considerar a possibilidade do enfraquecimento do poder de direção e de formação do consenso da classe que detém o poder econômico e político, criando o terreno para o confronto entre uma hegemonia em "crise" e outra que ainda não nasceu ${ }^{10}$.

A centralidade reflexiva de Gramsci está em desocultar as mediações pelas quais o Estado - esfera em que se efetiva a unificação e o exercício da dominação da burguesia, como já explicitara a teoria marxiana e Lênin - consolida e reproduz a dominação de classe. Como evidenciado, essa dominação não se materializava somente pela repressão, mas, também, inclui a direção de classe nos complexos da superestrutura pela via da aceitação consensual de suas diretivas pelos setores subalternos. Situa-se, aqui, na reflexão acerca dos processos de manutenção da hegemonia ou de formação de uma nova hegemonia a definição conceitual mais precisa da questão da política em Gramsci, expressa na passagem em que define a "pequena" e a "grande" política. Nos fenômenos afetos à "pequena" política, temos os processos políticos voltados para a manutenção e /ou à justificação das relações de poder das frações da classe dominante ${ }^{11}$. Já os processos políticos da "grande" política compõem os conteúdos políticoorganizativos e ideológicos que expressam o que Gramsci denomina, nos Cadernos, de catarse.

\footnotetext{
10 "Isso nos diz que o conceito de hegemonia é apresentado por Gramsci em toda a sua amplitude, isto é, como algo que opera não apenas sobre a estrutura econômica e sobre a organização política da sociedade, mas também sobre o modo de pensar, sobre as orientações ideológicas e inclusive sobre o modo de conhecer" Gruppi (2000, p.3). Se para Gramsci (2000b: 331), "[...] Estado é todo o complexo de atividades práticas e teóricas com as quais a classe dirigente não só justifica e mantém seu domínio, mas consegue obter o consenso ativo dos governados $[\ldots] "$, torna-se fundamental o entendimento do conjunto de mediações que conformam e esclarecem esse domínio e seu consentimento: como se governa e por que o governado obedece. Segundo Coutinho (1994: 111), muitas das reflexões gramscianas buscam esclarecer essa questão, o que the permite desenvolver e introduzir novas determinações nos conceitos de coerção e de consenso.

11 Para Gramsci (2000b: 21), a "pequena política (política do dia-a-dia, política parlamentar, de corredor, de intrigas"que "compreende as questões parciais e cotidianas que se apresentam no interior de uma estrutura já estabelecida em decorrência de lutas pela predominância entre as diversas frações de uma mesma classe política") expressa os processos políticos que legitimam e perpetuam a divisão de classes e de poder político.
} 
Os processos políticos que conformam a "grande" política se materializam por meio das conquista progressiva de uma unidade político-ideológica das classes subalternas,alargando e articulando seus interesses e necessidades na busca da superação dos seus limites corporativos. Esse é o processo e o momento que Gramsci denomina de "catarse", isto é, "[...] a passagem do momento meramente econômico (ou egoístico-passional) ao momento éticopolítico, isto é, a elaboração superior da estrutura em superestrutura na consciência dos homens" (GRAMSCI, 2001: 53) ${ }^{12}$.

\section{2-Lutas de classe e processos políticos: catarse, partido e estratégias revolucionárias}

No item anterior, foram explicitadas algumas das principais categorias que fundamentam a concepção da questão da política desenvolvida pelo marxista italiano, a qual encontra nos conteúdos que desenvolveu para os processos de formação da consciência de classe - tratada no que nominou de catarse -; na centralidade do partido e no seu tratamento das estratégias revolucionárias as prospectivas mais diretamente ligadas às condições ideopolíticas de superação da ordem do capital.

\section{Catarse e a função do partido}

Gramsci desenvolve, ao tratar dos processos de formação de consciência que são por ele postos em relevo sob a nominação de catarse, a questão da passagem do momento econômico-corporativo ao ético-político, que se efetivaria pela via da ação crítica, classista e organizada das classes subalternas na direção da percepção e da formação de seus interesses universais, que ele chamou de "consciência ético-política" ${ }^{13}$. Segundo Coutinho (1994: 106),

o conceito de catarse tem assim, para Gramsci, uma dimensão claramente política: o momento "catártico" é aquele em que o homem afirma sua liberdade em face das estruturas sociais, revelando que - embora condicionado pelas estruturas e, em particular, pelas estruturas econômicas é capaz ao mesmo tempo, de utilizar o conhecimento dessas estruturas como fundamento para uma práxis autônoma, para a criação de novas estruturas, ou, como ele diz, para "gerar novas iniciativas".

Os processos de mediação da formação de consciência econômico-corporativa à éticopolítica são explicitados, por Gramsci, quando destaca três momentos do grau de

\footnotetext{
${ }^{12}$ A passagem de uma consciência reivindicatória para uma consciência da totalidade da realidade social está presente no processo que Marx (1982) denomina da transição da "classe em-si" à "classe para-si"; na elevação da consciência sindical à político-universal de Lênin (2010) e na concepção de "catarse" em Gramsci.

${ }^{13}$ Nas esclarecedoras palavras de Coutinho (1994: 158-9), "em Gramsci, o momento catártico - que ele chega mesmo a conceber como sinônimo de práxis política - é o processo mediante o qual um grupo social supera seus interesses econômicos, meramente corporativos ou "egoístico-passionais", e se eleva à consciência "éticopolítica", à condição de classe universal, capaz de se tornar hegemônica por dar respostas historicamente universais às questões vividas pelo povo-nação e pela humanidade numa época concreta".
} 
homogeneidade, de organização e consciência ideo-política alcançado pelos grupos sociais subalternos: o primeiro é o momento econômico-corporativo, no qual o grupo profissional toma consciência dos seus interesses e do dever de organizá-los, mas não desenvolveu ainda unidade com o grupo social mais amplo; o segundo é o momento sindicalista, "em que se atinge a consciência da solidariedade de interesses entre todos os membros do grupo social,mas ainda no campo meramente econômico". O terceiro momento é aquele em que se atinge a consciência de classe ou da fase hegemônica, "em que se adquire a consciência de que os próprios interesses corporativos, em seu desenvolvimento atual e futuro, superam o círculo corporativo [...] e podem e devem tornar-se os interesses de outros grupos subordinados. Esta é fase [...] além da unicidade dos fins econômicos e políticos, também aunidade intelectual e moral, pondo todas as questões em torno das quais ferve a luta não noplano corporativo, mas num plano 'universal' [...]" (GRAMSCI, 2000b: 41).

O desenvolvimento de uma consciência crítica em relação à hegemonia vigente - nas formações sociais em que as superestruturas apresentam uma alta complexidade sócioinstitucional e político-ideológica - requer uma intensa "preparação ideológica das massas", um "trabalho de crítica, de penetração cultural, de permeação de idéias", de construção de uma nova concepção de mundo (de uma "reforma intelectual e moral"). Daí a importância fundamental que Gramsci atribui à função dos intelectuais orgânicos.

Para Gramsci, os intelectuais orgânicos são criados a partir da inserção e da função de cada grupo social na esfera da produção e do conjunto das relações sociais. São os intelectuais "[...] que lhe dão homogeneidade e consciência da própria função, não apenas no campo econômico, mas também no social e político [...]" (GRAMSCI, 2000a, p.15). Na ação dos intelectuais das classes subalternas, a base do conhecimento para o convencimento está na apreensão das normas ou valores (concepção de mundo, linguagem,senso comum etc.) que informam a práxis cultural e política do indivíduo ou sujeitos sociais (como se dão as formas de consciência e como estas se relacionam e se manifestam com a práxis política) e também nas normas e valores utilizados para o convencimento (que devem ser dirigidos para a formação da vontade coletiva). Foi a esse tipo de conhecimento que Gramsci denominou de ideologia, ou seja, àquela relação entre conhecimento e ação que é mobilizada para a partilha de valores e ações comuns. Em suas análises, Gramsci (2001: 237) distingue as ideologias que são "historicamente orgânicas", na expressividade dos processos sociais de organização das classes e da ordem social, daquelas que são "arbitrárias", ou seja, que impulsionam de forma pouco duradoura a ação humana. As primeiras formam o terreno no qual os homens adquirem consciênciade sua posição de classe, lutam enquanto que as segundas não criam senão ações 
individuais em pequenos grupos, expressão da "pequena política". É na esfera das ideologias orgânicas que se expressa o campo da luta política entre diferentes concepções de mundo pela conquista da hegemonia. É nela o campo da "grande política". Gramsci situa sua "filosofia da práxis" nesse terreno de luta das ideologias orgânicas e na participação ativa dos setores subalternos na busca da superação e destruição da relação "hegemônica" entre governantes e governados e da formação de uma nova hegemonia.

Para Gramsci, a imposição ou adesão passiva ao consenso dirigido pela classe dominante é resultado do fato de ser a detentora do poder econômico e dos principais portadores e divulgadores de sua hegemonia: o poder estatal e suas organizações na sociedade civil. São inicialmente estas últimas que formam o aparelho da hegemonia política e cultural das classes dominantes, é exatamente aí que exercem a direção sobre as demais classes.

É no cômputo de uma complexa e progressiva passagem da consciência e da prática "egoístico-passional" para a "ético-política" que se constitui e que se pensa a questão da "grande política" em Gramsci e, correlata a ela, a questão do partido como um tipo particular e central de intelectual orgânico e coletivo. Caberia centralmente ao partido operar a superação dos momentos econômico-corporativos dos grupos sociais (que encontram, por exemplo, nos sindicatos as suas expressões) e se tornarem "agentes de atividades gerais, de caráter nacional e internacional". Todos os membros de um partido político são considerados intelectuais, mas o significado forte é para aqueles que exercem uma função que é "diretiva e organizativa, isto é educativa, isto é, intelectual" Gramsci (2000a: 25) Duriguetto (2014: 288).

Nesse campo de discussão sobre a função dos intelectuais, especialmente de determinada função intelectual, a do partido, nos processos de formação de uma consciência ético-política que supere a mera apreensão e ação corporativa, é pertinente destacarmos, novamente, a nota intitulada "Análise das situações. Correlação de forças". Aqui, Gramsci examina os diversos "momentos" ou "graus" em que se articulam as relações de forças entre as classes sociais, objetivando identificar as situações que "sugerem as operações táticas imediatas, indicam a melhor maneira de empreender uma campanha de agitação política, a linguagem que será maisbem compreendida pelas multidões, etc.” (GRAMSCI, 2000b: 19).

O primeiro nível de análise que examina as relações de força é o econômico, ou seja, é aquele ligado à estrutura objetiva, do grau de desenvolvimento das forças materiais de produção em que se têm os agrupamentos sociais e suas funções e posições na divisão social do trabalho. Trata-se da base objetiva na qual se estabelece, com realismo, a análise da relação e situação política das forças sociais.

É no segundo nível - o das "relações das forças políticas" -, que se estabelece a 
identificação do grau de homogeneidade, de organização e consciência ideo-política alcançado pelos vários grupos sociais: o primeiro é o momento econômico-corporativo, no qual o grupo profissional toma consciência dos seus interesses e do dever de organizá-los, mas não desenvolveu ainda unidade com o grupo social mais amplo; o segundo é o momento sindicalista, "em que se atinge a consciência da solidariedade de interesses entre todos os membros do grupo social, mas ainda no campo meramente econômico". A questão do Estado é posta nesse momento "apenas no terreno da obtenção de uma igualdade político-jurídica com os grupos dominantes, já que se reivindica o direito de participar da legislação e da administração e mesmo de modificá-las, de reformá-las, mas nos quadros fundamentais existentes".

O terceiro momento apresenta

[...] a fase mais estritamente política, que assinala a passagem nítida da estruturapara a esfera das superestruturas complexas; é a fase em que as ideologias geradas anteriormente se transformam em 'partido', entram em confrontação e lutam até que uma delas, ou pelo menos uma única combinação delas, tenda a prevalecer, a se impor, a se irradiar por toda a área social, determinando, além daunicidade dos fins econômicos e políticos, também a unidade intelectual e moral,pondo todas as questões em torno das quais ferve a luta não no plano corporativo, mas num plano 'universal', criando assim a hegemonia de um grupo social fundamental sobre uma série de grupos subordinados (GRAMSCI, 2000b: 40-1, Grifos nossos).

É nesse terceiro momento, interno às relações das forças políticas, que se pode identificar a formação de uma consciência ético-política de classe, em que está posta a questão da fundação de uma nova hegemonia de classe ${ }^{14}$. Como explicita Coutinho (1991, p.105-6), para Gramsci, a possibilidade da construção de uma nova hegemonia está na capacidade de formação de uma vontade coletiva revolucionária dirigida pelas classes subalternas. Nessa construção, o gramsciano brasileiro chama atenção para a centralidade das observações do marxista sardo acerca da necessidade da superação dos movimentos espontâneos pela direção política consciente, ou seja, por "uma síntese político-intelectual que supere os elementos de corporativismo e transforme tais movimentos em algo homogêneo, universalizante, capaz de ação eficaz e duradoura". Para Gramsci, os "sentimentos espontâneos" das massas, prossegue Coutinho, devem ser "educados", "orientados" e é da "unidade da espontaneidade" com a “direção consciente" que se deve desenvolver a ação política das classes subalternas. Essa função de síntese e de mediação caberia aos intelectuais orgânicos do partido, ao "Moderno

\footnotetext{
${ }^{14} \mathrm{~A}$ análise das relações de forças é completada por um terceiro nível, identificado por Gramsci como relação de forças militares. A interpretação do significado deste nível de análise das relações de forças abre uma polêmica sobre a estratégia revolucionária defendida por Gramsci, cuja discussão apresentamos, de forma breve, no próximo item.
} 
Príncipe". Também elucida Coutinho (COUTINHO, 1991: 106) que a "formação de uma vontade coletiva liga-se organicamente ao que Gramsci chama [...] de reforma intelectual e moral ${ }^{e e "}$. O Moderno Príncipe deve ser "ao mesmo tempo o organizador e expressão ativa e operante" dessa vontade e trabalhar por uma "reforma intelectual e moral" (GRAMSCI, 2000b, p.18), condição necessária para o processo de criação de uma nova hegemonia das classes subalternas e pela consequente criação da nova sociedade "regulada", termo usado por Gramsci para se referir à criação do "autogoverno dos produtores associados".

\section{Guerra de posição e guerra de movimento: estratégia e tática no processo revolucionário}

Como vimos no item anterior, sociedade civil e a sociedade política formam, no construto teórico-analítico de Gramsci, o Estado integral. Como implicações dessa concepção, Gramsci distingue dois tipos de configuração societal: "ocidental" e "oriental”. Na sociedade "oriental", há uma hipertrofia dos "aparelhos coercitivos" da sociedade política enquanto os "aparelhos privados" da sociedade civil são pouco desenvolvidos e organizados, não havendo, portanto, equilíbrio entre essas duas dimensões. Por outro lado, na sociedade "ocidental" configura-se a existência de um equilíbrio entre ambas. Essa percepção de Gramsci sobre diferentes tipos de sociedade o levou a definir estratégias revolucionárias diferenciadas para as formações econômico-sociais "ocidentais" e "orientais"15.

A "guerra de movimento", caracterizada pelo assalto ao Estado realizado pelos agentes revolucionários, com o objetivo de tomar o poder central e implementar uma nova ordem, era uma estratégia que só poderia ser utilizada em sociedades que possuíam umpolo de poder centralizado e nas quais a sociedade civil fosse frágil. Portanto, era uma estratégia revolucionária para o "Oriente". Nas sociedades capitalistas avançadas, a sociedade civil apresenta-se com autonomia relativa, tanto funcional quanto material, em relação à sociedade política. Por isso, numa sociedade “ocidentalizada", em que sociedade civil e sociedade política estão em equilíbrio de forças, o poder é exercido por meio da coerção, mas, também, da busca e da manutenção do consenso. Portanto, a estratégia revolucionária, nessa configuração de "equilíbrio", incorporaria a disputa da hegemonia nos aparelhos privados da sociedade civil, base material através da qual se processa uma das disputas pela hegemonia.

Nesse sentido, para Gramsci, a sociedade civil transformaria-se no espaço privilegiado

\footnotetext{
${ }^{15}$ A distinção entre "ocidente" e "oriente" em Gramsci, não se refere a posições geográficas e nem a períodos históricos demarcados. Na formulação, em nível de abstração mais elevada, o sardo comunista afirma que no "Oriente, o Estado era tudo, a sociedade civil era primitiva e gelatinosa; no Ocidente, havia entre o Estado e a sociedade civil uma justa relação e, ao oscilar o Estado, podia-se imediatamente reconhecer uma robusta estrutura da sociedade civil" (GRAMSCI, 2000b: 262).
} 
para o desenvolvimento dos processos organizativos e ideo-políticos de disputa pelo poder, portanto, pela hegemonia. "Guerra de posição" é o nome empregado por Gramsci para definir essa estratégia que propõe, antes da tomada do poder de Estado, a obtenção da hegemonia das classes subalternas - por meio da disputa nos aparelhos da sociedade civil -, visando à conquista progressiva de uma unidade político-ideológica - de uma direção de classe - para constituir um novo bloco histórico, o qual, inicialmente, altera a correlação de forças na sociedade e termina por impor a ascensão de uma nova classe ao poder. A construção desta "contra-hegemonia", em termos nossos, requer, assim, a busca do consenso dos grupos sociais aliados, alargando e articulando seus interesses e necessidades na busca da superação dos limites dos seus interesses corporativos.

A formulação dessas estratégias revolucionárias articuladas à configuração societal existente ("oriental" e "ocidental”) é indicada pelo marxista italiano ao apontar que o conceito de "revolução permanente", surgido antes de 1848, é adequado a um período histórico quando os aparelhos privados de hegemonia não se encontravam tão desenvolvidos (partidos de massa, grandes sindicatos, organizações culturais diversas). Por outro lado, a partir de 1870, com a “expansão colonial europeia, todos esses elementos se modificam, as relações de organização internas e internacionais do Estado tornam-se mais complexas e robustas; e a fórmula da 'revolução permanente' [...] é elaborada e superada [...] com a fórmula de 'hegemonia civil'” (GRAMSCI, 2000b: 24). Ou seja, a complexificação da sociedade capitalista levou à necessidade de redefinição da estratégia revolucionária a ser adotada: “ocorre na arte política o que ocorre na arte militar: a guerra de movimento torna-se cada vez mais guerra de posição" (GRAMSCI, 2000b: 24).

No entanto, a hegemonia da estratégia da "guerra de posição" sobre a "guerra de movimento" não significa a supressão desta última no processo revolucionário. A formulação gramsciana apenas sinaliza, o que não é pouco, que a estratégia central da revolução nos países ocidentais se concentraria nos processos que envolvem a "guerra de posição". Esta relação dialética entre "guerra de posição" e "guerra de movimento" é outro aspecto mal compreendido por intérpretes que imputam a Gramsci uma perspectiva reformista e politicista, na acepção indicada neste artigo.

Conforme elaborado por Gramsci (2000b: 72-73).

nas guerras entre os Estados mais avançados do ponto de vista civil e industrial, a guerra manobrada [ou de movimento] deve ser considerada como reduzida mais as funções táticas do que estratégicas [...]. A mesma transformação deve ocorrer na arte e na ciência política, pelo menos no que se refere aos Estados mais avançados onde a "sociedade civil" tornou-se uma estrutura muito complexa e resistente às "irrupções" catastróficas do elemento 
econômico imediato (crises, depressões, etc.); as superestruturas da sociedade civil são como o sistema das trincheiras na guerra moderna.

Guimarães (1998: 265-6) corrobora com esta interpretação e indica que "em Gramsci, a concepção de revolução em sua dimensão de violência está radicalmente subordinada a sua dimensão diretiva [...]. Pois o processo de construção da hegemonia [...] intrinsecamente deprime o momento de pura força no processo de transformação".

Dessa forma, entendemos que o marxista italiano não elimina a utilização da "guerra de movimento" no processo revolucionário, sua manutenção, mesmo nas sociedades avançadas, nas democracias modernas, continua válida para a análise e utilização nos processos revolucionários. Entretanto, entendemos que a questão central refere-se à dimensão estratégica da luta que, nessas sociedades, se concentraria na "guerra de posição". Parece-nos inconteste esta interpretação e não a noção indiferenciada da utilização de uma ou outra estratégia a depender do contexto político. Em outras palavras, a estratégia é a "guerra de posição" e esta estratégia não dispensa, ou melhor, requer a utilização da "guerra de movimento" em determinados momentos do processo revolucionário.

Esta questão de se pensar as estratégias revolucionárias não em excludência, mas, na materialidade concreta dos processos sócio-históricos está diretamente relacionada com a correta apreensão que, em Gramsci, há uma distinção "não orgânica", e sim dialética (de unidade-distinção) entre sociedade política e sociedade civil Liguori (2007: 16) ${ }^{16}$. Nesta direção, Gramsci seria sofisticadamente idílico se pensasse que uma transformação revolucionária de um modo de produção e padrão de acumulação poderia se processar somente pela via da organização crítica e classista das classes subalternas e em suas lutas cotidianas por tomadas de posição no seio dos aparelhos privados de hegemonia, sem precisar, em determinadas condições históricas concretas, utilizar o expediente tático da guerra de movimento. Por apreender que o Estado envolve ineliminavelmente uma dimensão coercitiva para a manutenção da hegemonia da classe e frações de classe que detém o poder e a concentração de riqueza na esfera produtiva e, consequentemente, na sociedade civil e na sociedade política, que Gramsci não descarta a função tática da "guerra de movimento" na supressão da ordem do capital.

Para finalizar, é fundamental enfatizar que o conjunto da reflexão gramsciana sobre as

\footnotetext{
16 Afirma o autor: "Não me parece que desse modo se perca a especificidade da teoria gramsciana da hegemonia, baseada no consenso [...], mas somente que se desminta uma interpretação da mesma em que exista unicamente o consenso, só os 'aparelhos hegemônicos'. A complexidade do papel do Estado ('integral') reside no fato de reunir força e consenso num nexo dialético, de unidade-distinção, no qual, em geral, no 'ocidente' o elemento do consenso é o que predomina, sem que evidentemente a 'força' desapareça. Tal como o demonstram até mesmo os casos extremos do fascismo e do nazismo" (LIGUORI, 2007, p.16-7; grifo do autor).
} 
estratégias revolucionárias tem como escopo a construção da "sociedade regulada" que, como bem analisa Coutinho (1992: 81), se refere ao "processo de extinção do Estado na sociedade comunista sem classe". Processo que, na formulação gramsciana, expressa o movimento de "reabsorção da sociedade política na sociedade civil", isto é, um movimento que afirma "como finalidade do Estado seu próprio fim, seu próprio desaparecimento" (GRAMSCI, 2000b: 223).

\section{Uma Consideração Final}

Os conteúdos teórico-analíticos e políticos das categorias gramscianas, sumariamente apresentadas neste artigo (estrutura, superestrutura, Estado integral, catarse, hegemonia, guerra de movimento e guerra de posição) evidenciam elementos centrais de como Gramsci refletiu e prospectivou a questão da política - tanto suas bases de manutenção da hegemonia da classe e frações de classe que detém o poder da dominação econômica na esfera da produção e as formas e mediações pelas quais essa dominação se espressa no aparato estatal por meio das esferas da sociedade civil e da sociedade política; quanto por refletir sobre prospectivas ideo-políticas que possam conduzir as classes subalternas à formação de uma consciência ético-política de seus interesses e projetos para a necessária erradicação do aparato estatal e a condução da vida social por uma sociedade regulada pelas necessidades dos trabalhadores e trabalhadoras livres. $\mathrm{Ou}$ seja, em Gramsci, a questão da política é refletida para explicar a manutenção de hegemonia, mas, também, para fomentar e induzir uma perspectiva revolucionária no conjunto das ações e organizações das classes subalternas.

Essa perspectiva de política revolucionária tratada pelo sardo comunista implica a construção de uma sociabilidade superior cuja materialização encontra-se fundada nas transformações das condições econômicas da produção da riqueza e de sua apropriação privada pelos detentores dos meios de produção. Essa perspectiva de política revolucionária tratada pelo sardo comunista implica a derrocada do aparato estatal integral e, com ela, as formas de dominação política, de uso da força, de controle e propagação ideológica que legitima a ordem do capital espraiados pelos aparelhos que compõem a sociedade política e a sociedade civil. Essa perspectiva de política revolucionária tratada pelo sardo comunista não comporta interpretações que a adjetivam como reformista e/ou politicista. Nem as dos intérpretes que se opõem a Gramsci, portanto, aos antigramscianos, nem aos que se proclamam gramscianos mas que, também, colorem seu pensamento do palatável reformismo e culturalismo.

\section{Referências}

BOBBIO, N. O conceito de sociedade civil. Rio de Janeiro: Graal, 1982. 
COUTINHO, C. N. Gramsci: um estudo sobre seu pensamento político. Rio de Janeiro: Campus, 1991. . Marxismo e Política. Rio de Janeiro: Cortez, 1994 . De Rousseau a Gramsci. São Paulo: Boitempo, 2011.

DURIGUETTO, M. L. “A questão dos intelectuais em Gramsci” in Revista Serv. Soc. Soc., São Paulo, n. 118, p. 265-293, abr./jun. 201.

FONTES, V. "Sociedade civil no Brasil contemporâneo: lutas sociais e luta teórica na década de 1980"; in Lima, J. C. F. e Neves, L. Ma. W. (orgs). Fundamentos da EducaçãoEscolar do Brasil Contemporâneo. Rio de Janeiro J: Fiocruz, 2007.

GRUPPI, L. O conceito de hegemonia em Gramsci. Rio de Janeiro: Graal, 2000.

GRAMSCI, A. Cadernos do cárcere. Rio de Janeiro: Civilização Brasileira, 2000a, vol. 2. . Cadernos do cárcere. Rio de Janeiro: Civilização Brasileira, 2000b, vol. 3. . Cadernos do cárcere. Rio de Janeiro: Civilização Brasileira, 2001, vol. 1.

GUIMARÃES, J. Democracia e marxismo: crítica à razão liberal. São Paulo: Xamã, 1998.

LÊNIN, V. I. O que fazer? São Paulo: Expressão Popular, 2010.

LIGUORI, G. Roteiros para Gramsci. Rio de Janeiro: Editora da UFRJ, 2007.

MARX, K. "Para a crítica da economia política". Coleção Os Pensadores. São Paulo. Editora Nova Cultural, 1996. . Miséria da Filosofia. São Paulo: Ciências Humanas, 1982. . MARX, K e ENGELS, F. Obras Escolhidas: Rio de Janeiro, v. 1, 1956. "Crítica del derecho del Estado de Hegel” In: Obras de Marx y Engels Vol 5, 1978.

NETTO, J.P. Capitalismo Monopolista e Serviço Social. São Paulo: Cortez,1992.

PORTELLI, H. Gramsci e o bloco histórico. Rio de Janeiro: Paz e Terra, 1977.

PRZEWORSKI, A. Capitalismo e social-democracia. São Paulo:Companhia das Letras, 1989. VOZA, P. "Estrutura" In: LIGUORI, G. E VOZA, P (orgs.). Dicionário Gramsciano. São Paulo:Boitempo, 2014 